\title{
Pertumbuhan Jaringan Stipe dari Jamur Sagu (Volvariella sp) Endemik Papua dalam Kultur in vitro
}

\author{
Barahima Abbas*), Florentina Heningtyas Listyorini, Eko Agus Martanto, \\ dan Yanuarius Renwarin
}

Fakultas Pertanian dan Teknologi Pertanian, Universitas Negeri Papua, Papua Barat 98314

Diterima 27-01-2010 Disetujui 13-03-2012

\begin{abstract}
Sago mushrooms are edible fungus which it grew naturally on decaying sago pith. The objectives of the research were defined an appropriate formulation medium for growth and development of stipe tissue of sago mushroom in order to result spawn stages. The parent of the tissues used as explants were selected from the best performance of sago mushroom which grew naturally. The research divided into three experiments: 1) Initiation of growth hyphae from stipe tissue; 2) hyphae proliferation; and 3) spawn formation. Murashige and Skoog (MS) and Knudson-C (KN) medium enriched 15 and $30 \%$ coconut water are the best medium for growth initiation and proliferation of hyphae. Both of these medium induced the explant grew rapidly and resulted vigorous hyphae. No different effect among concentration treatment of coconut water was observed for initiation and proliferation hyphae. The fact that all of the formulation medium used for spawn formation were able to induce spawn development become spawn stage. Even so, the best mediums for spawn formation were medium formulation 9 and 10 .
\end{abstract}

Keywords: endemic, in vitro, papua, sago mushroom, Volvariella sp

\begin{abstract}
ABSTRAK
Jamur sagu (Volvariella sp.) adalah jamur pangan yang tumbuh secara alami pada ampas sagu yang sedang melapuk. Penelitian ini bertujuan menentukan formulasi media yang sesuai untuk pertumbuhan dan perkembangan jaringan tungkai dari jamur sagu untuk menghasilkan biakan induk jamur sagu. Tetua jamur sagu yang digunakan sebagai sumber eksplan merupakan jamur sagu yang tumbuh secara alami (wild types) di tempat buangan ampas sagu yang sedang melapuk. Penelitian ini terdiri atas tiga percobaan, yaitu: 1) inisiasi pertumbuhan hifa dari jaringan stipe; 2) proliferasi hifa; dan 3) pembentukan spawn. Media yang terbaik untuk inisiasi pertumbuhan dan proliferasi hifa adalah media MS dan KN yang diperkaya dengan air kelapa 15 dan 30\%. Kedua media tersebut menginduksi pertumbuhan eksplan dengan cepat dan menghasilkan hifa yang vigor. Tidak ada perbedaan di antara perlakuan air kelapa yang dicobakan pada proses inisiasi dan proliferasi hifa jamur sagu. Faktanya, semua formulasi media biji-bijian yang digunakan pada penelitian ini dapat digunakan sebagai media untuk menghasilkan biakan induk (spawn stages) jamur sagu. Formulasi media sorgum (formulasi media 9 dan 10) merupakan media yang terbaik menginduksi pertumbuhan dan perkembangan miselium menjadi biakan induk.
\end{abstract}

Kata Kunci: endemik, in vitro, papua, jamur sagu, Volvariella sp

\section{PENDAHULUAN}

Jamur sagu (Volvariella sp.) adalah jamur yang tumbuh secara alami di ampas sagu yang sedang melapuk. Keberadaan jamur sagu yang tumbuh secara alami tidak menentu dan jarang dijumpai. Masyarakat senang sekali bila menemui jamur sagu di hutan sagu. Ini dikarenakan jamur sagu memiliki rasa yang enak, lezat, dan kaya akan protein.

*Telp: +6285244696549

Email: barahimabas@yahoo.com
Kandungan nutrisi jamur sagu tiap $100 \mathrm{~g}$ berat basah adalah protein $4 \mathrm{~g}$, karbohidrat 2,99 g, lemak 0,19 g, kalsium 11,53 mg, fosfor 0,31 g, dan kalium 165,05 mg (Abbas \& Listyorini 2009). Jamur sagu dan jamur edibel lainnya juga kaya akan asam amino esensial seperti leusin, isoleusin, valin, tryptophan, lysin, theonin, phenilalanin, methinin dan histidin (Jordan 1993). Jamur edibel juga kaya akan asam lemak tidak jenuh, dapat menurunkan kadar 
kolesterol Low Density Lipoprotein (LDL) dalam darah (Chang 1999). Di samping itu jamur juga memiliki anti virus dan bakteri, sehingga meningkatkan daya tahan tubuh terhadap penyakit.

Peluang bisnis jamur pangan (edibel), termasuk jamur sagu memiliki prospek yang baik karena harganya yang mahal dan peluang pasar ekspor yang terbuka luas. Kebutuhan jamur edibel saat ini 35\% pasar dalam negeri dan 65\% pasar luar negeri (Mohi 2007). Selanjutnya diungkapkan bahwa kebutuhan jamur edibel dunia mencapai 1.142.500 MT, yang terdiri atas pasar Eropa 402.500 MT, Asia dan Australia 3.000 MT, USA 486.000 MT, Jepang dan Arab 1.000 MT, Indonesia sendiri sebesar 32.000 MT dan negara lainnya 250.000 MT dengan harga US\$2,5-4 per Kg.

Bibit jamur sagu dapat dihasilkan dari spora dan tubuh buah seperti halnya jamur edibel lainnya. Bibit yang dihasilkan dari spora jamur akan menghasilkan bibit jamur yang sangat beragam (Atkin 1995). Bibit yang dihasilkan dari tubuh buah seperti dari jaringan tungkai (stipe) akan menghasilkan bibit dengan pertumbuhan yang seragam (Chang \& Hayer 1978). Untuk tujuan komersial, bibit yang dihasilkan dari tubuh buah jamur sagu yang dikehendaki karena memiliki pertumbuhan yang seragam dan bentuk tubuh buah yang tidak bervariasi, mengikuti bentuk tubuh buah dari tetuanya. Untuk tujuan mencari varietas unggul, maka bibit asal spora yang diinginkan karena variasinya tinggi. Penyediaan bibit jamur sagu secara konvensional belum pernah dijumpai ada yang berhasil. Salah satu metode yang ampuh dan terbukti dapat menumbuhkan sel dan jaringan dari organisme hidup, termasuk sel tubuh buah jamur sagu adalah teknologi kultur in vitro. Penelitian ini bertujuan menentukan media yang sesuai untuk pertumbuhan dan perkembangan jaringan stipe dari jamur sagu untuk menghasilkan biakan induk jamur sagu.

\section{BAHAN DAN METODE}

Lokasi Penelitian. Penelitian ini dilaksanakan di Desa Warari Kecamatan Yapen Selatan, Kabupaten Serui dan Laboratorium Bioteknologi Fapertek Universitas Negeri Papua. Peta lokasi tempat jamur sagu yang tumbuh alami di tempat buangan ampas sagu masyarakat yang dijadikan sumber eksplan disajikan pada Gambar 1.

Penentuan Eksplan. Tetua induk jamur sagu yang dijadikan donor eksplan tidak diambil secara acak dari jamur sagu yang tumbuh secara alami pada hamparan ampas sagu di alam, tetapi diseleksi. Seleksi dilakukan agar jamur sagu yang ditetapkan sebagai donor eksplan memiliki pertumbuhan yang subur, sehat, vigor, dan tidak terserang penyakit. Tubuh buah jamur sagu hasil seleksi dan representatif untuk dijadikan donor sel atau jaringan disterilisasi dengan menggunakan alkohol $95 \%$. Jaringan bagian dalam tungkai dari tubuh buah dikeluarkan untuk dijadikan eksplan dan dikulturkan pada media PDA, MS dan Knudson-C yang diperkaya dengan air kelapa.

Eksperimen Inisiasi Pertumbuhan Hifa. Eksperimen tahap pertama ini menggunakan jaringan tungkai sebagai eksplan. Eksperimen ini dirancang dengan menggunakan rancangan acak lengkap (RAL) berfaktor. Perlakuan terdiri atas dua faktor yaitu faktor jenis media dasar dan air kelapa. Faktor pertama terdiri atas tiga macam media, yaitu: media PDA, MS, dan Knudson. Faktor kedua terdiri atas empat level konsentrasi air kelapa, yaitu: 0, 15, 30, dan 45\%. Masing-masing perlakuan diulang sebanyak 5 kali, sehingga seluruhnya terdapat 45 satuan percobaan.

Eksperimen Proliferasi Hifa. Eksperimen tahap dua menggunakan hifa yang dihasilkan dari eksperimen pertama sebagai eksplan. Eksperimen ini dirancang dengan menggunakan rancangan acak lengkap (RAL) berfaktor. Perlakuan terdiri atas dua faktor yaitu faktor jenis media dasar dan air kelapa. Faktor pertama terdiri atas tiga macam media, yaitu: media PDA, MS, dan Knudson. Faktor kedua terdiri atas empat level konsentrasi air kelapa, yaitu: 0, 15, 30, dan 45\%. Masing-masing perlakuan diulang sebanyak 5 kali, sehingga seluruhnya terdapat 45 satuan percobaan.

Eksperimen Pembentukan spawn. Eksperimen tahap tiga menggunakan miselia yang dihasilkan dari eksperimen tahap 2 sebagai eksplan. Eksperimen ini dirancang dengan menggunakan RAL yang terdiri atas 12 perlakuan.

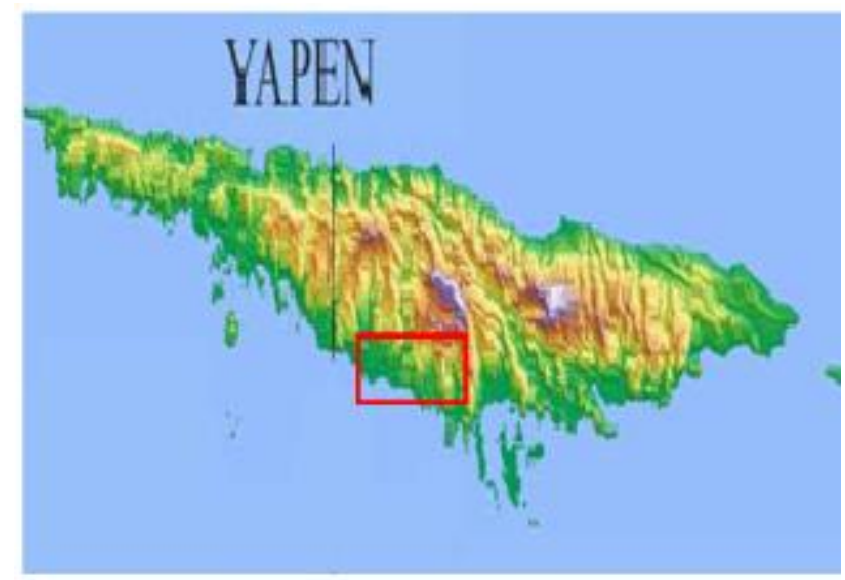

Gambar 1 Lokasi tempat sampel tetua jamur sagu didapatkan dan digunakan sebagai sumber eksplan pada penelitian ini (kotak merah) 
Perlakuan 1, yaitu: formulasi campuran biji kacang hijau, tepung sagu, dan kapur dengan perbandingan 10:1:0,05. Perlakuan 2, yaitu: formulasi campuran biji kacang hijau, tepung sagu, dan kapur dengan perbandingan 10:1:0,1. Perlakuan 3, yaitu: formulasi campuran biji kacang merah, tepung sagu, dan kapur dengan perbandingan 10:1:0,05. Perlakuan 4, yaitu: formulasi campuran biji kacang merah, tepung sagu, dan kapur dengan perbandingan 10:1:0,1. Perlakuan 5, yaitu: formulasi campuran biji jagung, tepung sagu, dan kapur dengan perbandingan 10:1:0,05. Perlakuan 6, yaitu: formulasi campuran biji jagung, tepung sagu, dan kapur dengan perbandingan 10:1:0,05. Perlakuan 7, yaitu: formulasi campuran biji kedelai, tepung sagu, dan kapur dengan perbandingan 10:1:0,05. Perlakuan 8, yaitu: formulasi campuran biji kedelai, tepung sagu, dan kapur dengan perbandingan 10:1:0,1. Perlakuan 9, yaitu: formulasi campuran biji sorgum, tepung sagu, dan kapur dengan perbandingan 10:1:0,05. Perlakuan 10, yaitu: formulasi campuran biji sorgum, tepung sagu dan kapur dengan perbandingan 10:2:0,1. Perlakuan 11, yaitu: formulasi campuran biji sorgum, bekatul dan kapur dengan perbandingan 10:1:0,05. Perlakuan 12, yaitu: formulasi campuran biji sorgum, bekatul, dan kapur dengan perbandingan 10:2:0,1. Masing-masing perlakuan diulang sebanyak 5 kali, sehingga seluruhnya terdapat 60 satuan percobaan.

Analisis Data. Data kuantitatif dalam bentuk angkaangka yang diperoleh dari hasil pengukuran respon diolah dan dianalisis dengan menggunakan Analisis ragam (ANOVA). Analisis ragam dikalkulasi dengan menggunakan software MINITAB ver.13. Data kuantitatif dari masingmasing eksperimen yang menunjukkan hasil kalkulasi ANOVA berbeda nyata dilakukan uji lanjut. Uji lanjut yang digunakan, yaitu: uji Beda Nyata Jujur (BNJ) untuk menentukan perlakuan terbaik di antara perlakuan yang dicobakan dari masing-masing eksperimen. Data kualitatif diolah dan dianalisis dengan menggunakan kriteria. Kriteria yang digunakan, yaitu: tumbuh (+), tumbuh tidak bagus (++), tumbuh cukup bagus $(+++)$, tumbuh bagus $(++++)$, tumbuh sangat bagus $(+++++)$, dan tidak tumbuh $(-)$.

\section{HASIL DAN PEMBAHASAN}

Observasi Tetua Donor. Penampilan morfologi jamur sagu yang ditemukan tumbuh secara alami di Desa Warari, Kecamatan Yapen Selatan, kabupaten Yapen disajikan pada Gambar 2. Jamur sagu yang ditemukan itu tumbuh alami dan memiliki penampilan morfologi yang subur, sehat, tidak terserang hama dan penyakit. Dengan demikian jamur sagu baik untuk dijadikan tetua donor sel atau jaringan untuk menghasilkan biakan murni. Penampilan morfologi jamur sagu tersebut dibandingkan dengan penampilan morfologi berbagai spesies dari genus Volvariella yang telah diidentifikasi dan diberi nama oleh Kuo (2008) ternyata jamur sagu secara morfologi dan kandungan nutrisinya berbeda dengan spesies dari genus Volvariella lainnya, sehingga jamur sagu diduga merupakan spesies tersendiri di antara berbagai macam species jamur edibel dari genus Volvariella. Ciri utama jamur dari genus Volvariella yaitu adanya organ yang berbentuk selaput tipis yang menyelimuti bagian pangkal stipe dan merupakan pembungkus tubuh buah jamur saat masih muda yang disebut Volvas (Li 1982; \& Moncalvo et al. 2002).

Jamur sagu memiliki struktur tubuh buah yang cukup besar yaitu memiliki panjang stipe antara 7,5-12,5 cm dengan rata-rata $10,5 \mathrm{~cm}$, diameter stipe antara $0,3-0,7 \mathrm{~cm}$ dengan rata-rata $0,44 \mathrm{~cm}$, diameter pileus (tudung) antara $8-12 \mathrm{~cm}$ dengan rata $10,1 \mathrm{~cm}$. Chang (1983) mengungkapkan bahwa panjang stipe jamur merang sekitar 5-8 cm dengan diameter $0,5-1,5 \mathrm{~cm}$ dan berwarna putih. Kandungan nutrisinya yang dimiliki jamur sagu, yaitu: lemak jamur sagu sebesar 2,54\%; karbohidrat 39,97\%; dan protein 53,48\% (Abbas \& Listyorini 2009). Osemwegie et al. (2006) mengungkapkan bahwa kadar nutrisi yang dikandung jamur merang, yaitu: karbohidrat $12,63 \%$ dan protein $11,77 \%$. Selanjutnya Widyastuti (2005) mengungkapkan bahwa kadar protein jamur merang sebesar 25,9; dan lemak 2,4\% dan Istimewa (2008) mengungkapkan bahwa kandungan protein jamur merang sebesar $1,8 \%$, karbohidrat 12-48\%, dan lemak 0,3\% dari berat basah. Berdasarkan ciri-ciri jamur sagu yang dijadikan sumber eksplan menunjukkan bahwa jamur sagu berbeda dengan jamur dari genus Volvariella lainnya.

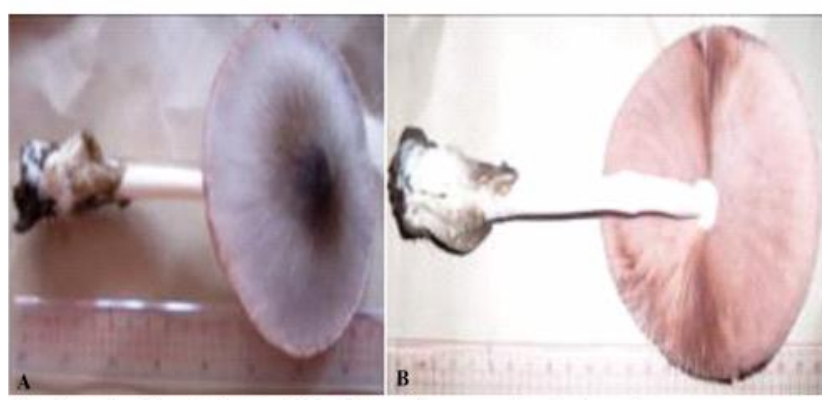

Gambar 2 Bentuk morfologi dan fase pertumbuhan jamur sagu yang dijadikan tetua donor untuk menghasilkan biakan murni. A) Penampilan bagian pileus, dan B) penampilan bagian lamella 
Inisiasi Pertumbuhan Hifa dari Jaringan Stipe. Jaringan stipe yang digunakan sebagai eksplan dapat tumbuh pada semua media tumbuh yang digunakan (MS, Knudson-C, dan PDA). Jaringan stipe yang dikulturkan pada media PDA yang tidak diberi perlakuan air kelapa sebagian besar mengalami fermentasi kemudian mati (Tabel 1). Media MS dan Knudson-C (KN) menginduksi pertumbuhan hifa jamur lebih baik diduga disebabkan komposisi hara yang terkandung pada media MS dan Knudson-C lebih lengkap dibanding dengan media PDA. Media MS memiliki komposisi yang lengkap terhadap unsur hara makro, mikro, dan vitamin (George \& Sherrington 1984; Pierik 1987). Air kelapa berpengaruh baik terhadap pertumbuhan hifa jamur sagu. Media yang tidak diperkaya dengan air kelapa (kontrol) memperlihatkan pertumbuhan hifa yang sangat lambat. Air kelapa kaya akan mineral dan vitamin. Mineral yang terkandung pada air kelapa yaitu $\mathrm{K}$, $\mathrm{Na}, \mathrm{Ca}, \mathrm{Mg}, \mathrm{Fe}, \mathrm{Cu}, \mathrm{P}$, dan S (Santoso 2003; Muhammed \& Vladimir 2007). Selanjutnya diungkapkan bahwa air kelapa juga mengandung vitamin $\mathrm{C}$, asam nikotinat, asam pantotenat, asam folat, biotin, dan riboflavin. Mineral dan vitamin, serta senyawa organik lain yang terdapat pada air kelapa diduga memacu pembelahan dan pertumbuhan sel jamur sagu membentuk hifa dengan cepat dibanding dengan media yang tanpa diberi air kelapa. Respon pertumbuhan sel dan jaringan yang baik akibat penambahan air kelapa dalam medium tumbuh juga dilaporkan dapat memacu pembelahan dan pertumbuhan sel-sel eksplan yang dikultur membentuk embriogenesis pada tanaman Gricinia manggostana L (Minth 2001).

Media yang diperkaya dengan air kelapa 15 dan $30 \%$ menginduksi pertumbuhan hifa jamur yang baik dibanding dengan perlakuan lainnya. Studi sebelumnya pada tumbuhan juga dilaporkan bahwa penambahan air kelapa $15 \%$ mempercepat pertumbuhan kalus, regenerasi tunas, dan pertumbuhan tunas pada Spinach oleracea L. (Khayri et al. 1992). Selanjutnya Peixe et al. (2007) melaporkan bahwa air

Tabel 1 Pertumbuhan jaringan stipe yang dikultur pada media MS, KN dan PDA yang diperkaya dengan empat macam konsentrasi air kelapa

\begin{tabular}{|c|c|c|c|c|}
\hline \multirow[t]{2}{*}{ Media } & \multicolumn{4}{|c|}{ Konsentrasi air kelapa } \\
\hline & $0 \%$ & $15 \%$ & $30 \%$ & $45 \%$ \\
\hline MS & + & +++++ & +++++ & ++++ \\
\hline $\mathrm{KN}$ & + & +++++ & +++++ & ++++ \\
\hline PDA & - & ++ & ++ & - \\
\hline
\end{tabular}

kelapa 5\% dan BAP $2.22 \mu \mathrm{M}$ berpengaruh baik pada perbanyakan mikro Olea europaea L. Syafii et al. (2000) melaporkan bahwa air kelapa $20 \%$ dapat memacu pertumbuhan kalus dan akar tanaman Cucumis melo var. Honey dew. Air kelapa selain dapat memacu pembelahan dan pertumbuhan sel tanaman, juga dapat memacu pertumbuhan dan proliferasi sel-sel jaringan stipe jamur sagu membentuk hifa yang melimpah. Media yang diperkaya dengan air kelapa $45 \%$ memperlihatkan pertumbuhan hifa yang baik dan tidak berbeda dibandingkan dengan media yang diperkaya dengan air kelapa 15 dan 30\% (Tabel 1 dan Tabel 2). Hal tersebut diduga disebabkan senyawa mineral dan senyawa organik yang terkandung pada air kelapa sudah terpenuhi kebutuhan untuk memacu pertumbuhan hifa jamur sagu pada saat diberikan $15 \%$, meskipun demikian pada konsentrasi 30 dan $45 \%$ belum bersifat inhibitor terhadap pertumbuhan hifa jamur. Data pengamatan pertumbuhan jaringan stipe pada berbagai media tumbuh yang dicobakan secara kualitatif disajikan pada Tabel 1 dan secara kuantitatif disajikan pada Tabel 2. Pertumbuhan hifa pada perlakuan media dasar MS dan KN yang tidak diperkaya dengan air kelapa memerlukan waktu 28 hari untuk dapat menutup seluruh permukaan media, tetapi media dasar MS dan KN yang diperkaya dengan air kelapa hanya diperlukan 8 hari untuk menutup seluruh permukaan media (Tabel 2). Kecepatan pertumbuhan hifa ditentukan berdasarkan waktu yang diperlukan oleh hifa untuk memenuhi seluruh permukaan media tumbuh yang digunakan. Kriteria penentuan proporsi pemenuhan hifa pada permukan media tumbuh yang digunakan disajikan pada Gambar 3.

Proliferasi Hifa Jamur Sagu. Hifa yang digunakan sebagai eksplan menunjukkan bahwa media MS, KN, dan PDA dapat menginduksi pertumbuhan dan perkembangan hifa jamur sagu. Media MS dan KN menginduksi pertumbuhan hifa jamur sagu lebih cepat dan berbeda nyata dengan media PDA (Tabel 3). Formula media MS dan KN yang memiliki kandungan unsur hara lebih lengkap diduga menyebabkan sel dari jaringan stipe dan sel-sel hifa dapat terinduksi pertumbuhan dan perkembangannya. Media MS

Tabel 2 Rata-rata kecepatan pertumbuhan hifa dari jaringan stipe pada media MS, KN, dan PDA yang diperkaya dengan air kelapa

\begin{tabular}{lcccc}
\hline \multirow{2}{*}{ Media } & \multicolumn{4}{c}{ Konsentrasi air kelapa } \\
\cline { 2 - 5 } & $0 \%$ & $15 \%$ & $30 \%$ & $45 \%$ \\
\hline MS & 27,8 hari & 7,6 hari & 7,6 hari & 7,6 hari \\
KN & 27,0 hari & 7,6 hari & 7,6 hari & 7,6 hari \\
PDA & Mati & 25,0 hari & 25,0 hari & Mati \\
\hline
\end{tabular}



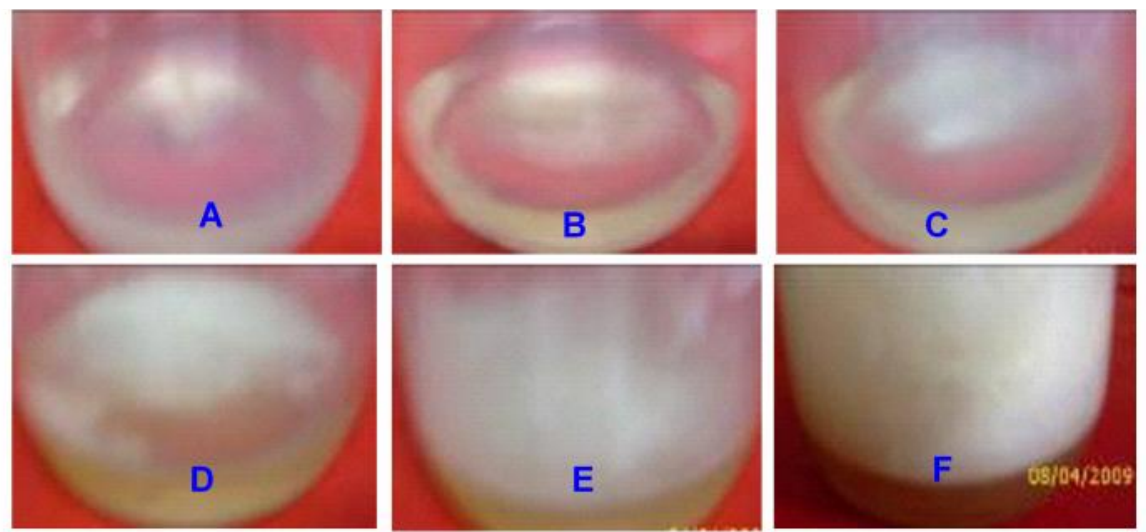

Gambar 3 Penentuan tingkat penutupan permukaan media dengan hifa. A) Penutupan 20\%; B) penutupan 40\%; C) penutupan 60\%; D) penutupan $80 \%$; E) penutupan $100 \%$; dan F) pertumbuhan hifa setelah melampaui tingkat penutupan $100 \%$

Tabel 3 Hasil analisis statistik pengaruh perlakuan media terhadap pertumbuhan hifa jamur sagu

\begin{tabular}{lccccc}
\hline \multicolumn{1}{c}{ Media dasar } & \multicolumn{5}{c}{ Air kelapa (\%) } \\
\cline { 2 - 6 } & 0 & 15 & 30 & 45 & $\begin{array}{c}\text { Rata-rata } \\
\text { (hari) }\end{array}$ \\
\hline MS & 21 & 8 & 8 & 8 & $11,2^{\text {a }}$ \\
KN & 21 & 8 & 8 & 8 & $11,2^{\text {a }}$ \\
PDA & 68 & 48 & 48 & 48 & $53,0^{\text {b }}$ \\
Rata-rata (hari) & $36,7^{\text {b }}$ & $21,3^{\text {a }}$ & $21,3^{\text {a }}$ & $21,3^{\text {a }}$ & \\
\hline Keterangan: angka yang diikuti oleh huruf yang sama tidak berbeda \\
nyata pada uji Tukey dengan tingkat kepercayaan \\
\\
$\begin{array}{l} \pm=0,05 \\
\end{array}$
\end{tabular}

dapat menginduksi pertumbuhan sel dari organ dan jaringan pada umumnya tanaman (George \& Sherrinton 1984; Dodds et al. 1986). Media KN yang diperkaya dengan air kelapa dapat menginduksi pertumbuhan biji anggrek Dendrobium sp. dengan baik (Pierik 1987).

Media MS, KN, dan PDA yang diperkaya dengan air kelapa menginduksi pertumbuhan hifa lebih cepat dan berbeda nyata dibanding dengan tanpa air kelapa (Tabel 3). Waktu yang diperlukan untuk menutupi seluruh permukaan media tumbuh dengan hifa bervariasi. Media MS dan KN yang diperkaya dengan air kelapa menginduksi pertumbuhan hifa jamur sagu lebih cepat, sehingga waktu yang diperlukan untuk menutup keseluruhan perumukaan media tumbuh lebih singkat (Tabel 3). Penelitian sebelumnya yang menggunakan air kelapa juga dilaporkan berpengaruh positif terhadap pertumbuhan sel-sel tanaman (Minh 2001; Roy \& Mandal 2005; Mukhtar et al. 2005). Muhammed dan Vladimir (2007) melaporkan bahwa air kelapa dapat menginduksi pertumbuhan jaringan mamalia. Selanjutnya Cordeiro et al. (2006) melaporkan bahwa air kelapa dapat digunakan untuk mempertahankan tetap immatur bovin oocytes dalam memproduksi embryo secara in vitro. Berdasarkan penelitian ini dan penelitian sebelumnya pada sel hewan dan tumbuhan dapat dikatakan bahwa air kelapa berpengaruh baik terhadap
Tabel 4 Hasil analisis statistik waktu yang diperlukan miselium untuk memenuhi seluruh permukaan media yang digunakan

\begin{tabular}{llc}
\hline No & \multicolumn{1}{c}{ Perlakuan } & Rata-rata hari \\
\hline 1 & Formulasi media 1 & $7,2 \mathrm{~d}$ \\
2 & Formulasi media 2 & $5,2 \mathrm{~b}$ \\
3 & Formulasi media 3 & $10,0 \mathrm{f}$ \\
4 & Formulasi media 4 & $5,0 \mathrm{~b}$ \\
5 & Formulasi media 5 & $8,0 \mathrm{e}$ \\
6 & Formulasi media 6 & $5,0 \mathrm{~b}$ \\
7 & Formulasi media 7 & $10,0 \mathrm{f}$ \\
8 & Formulasi media 8 & $5,0 \mathrm{~b}$ \\
9 & Formulasi media 9 & $3,0 \mathrm{a}$ \\
10 & Formulasi media 10 & $3,0 \mathrm{a}$ \\
11 & Formulasi media 11 & $6,0 \mathrm{c}$ \\
12 & Formulasi media 12 & $6,0 \mathrm{c}$ \\
\hline
\end{tabular}

Keterangan: angka yang diikuti oleh huruf yang sama tidak berbeda nyata pada uji Tukey dengan tingkat kepercayaan $\alpha=0,05$

pertumbuhan sel jamur, tumbuhan dan hewan. Respon proliferasi hifa-hifa jamur sagu tidak menunjukkan adanya perbedaan respon diantara perlakuan air kelapa yang dicobakan (15, 30, dan 45\%). Roy dan Mandal (2005) melaporkan hal yang serupa yaitu tidak terdapat perbedaan respon diantara perlakuan air kelapa 5, 10, dan 15\% terhadap pembentukan kalus androgenik pada tanaman padi.

Pertumbuhan Hifa pada Media Biji-bijian (media spawn). Hasil penelitian menunjukkan bahwa semua perlakuan biji-bijian yang dicobakan dapat menginduksi pertumbuhan hifa-hifa atau miselium. Tingkat kecepatan pertumbuhan miselium pada tiap-tiap media yang digunakan bervariasi. Perlakuan yang dapat menginduksi pertumbuhan miselium paling cepat yaitu perlakuan 9 (biji sorgum, yang ditambah $10 \%$ tepung sagu dan $0,5 \%$ kapur), dan perlakuan sepuluh (Biji Sorgum yang ditambah 10\% tepung sagu dan $1 \%$ kapur) hanya diperlukan waktu 3 hari untuk menutup seluruh permukan media dengan miselium (Tabel 4). Biji sorgum telah banyak digunakan dan dilaporkan sebagai media tumbuh miselia yang baik pada berbagai macam jamur 

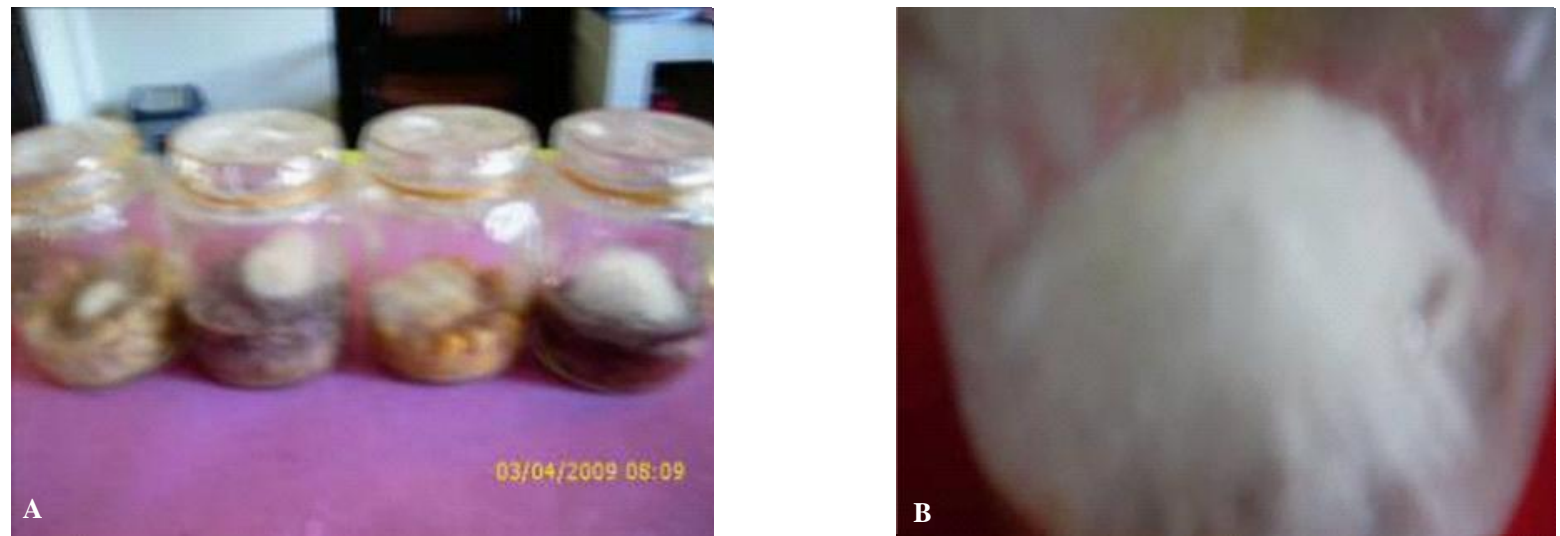

Gambar 4 Penampilan pertumbuhan dan perkembangan miselium pada media biji-bijian. A) Kecepatan pertumbuhan miselia dari media lambat ke media yang lebih cepat; B) media yang paling cepat

edibel. Mshandete dan Cuff (2008) melaporkan bahwa biji sorgum dapat menginduksi pertumbuhan miselium pada jamur Coprinus sinerius, Pleurotas flabellatus dan Volvariella volvacea dengan baik. Beausejour (1999) melaporkan bahwa biji gandum juga dapat digunakan sebagai spawn medium pada berbagai macam jamur. Perlakuan yang paling lambat menutup semua permukaan media dengan miselium yaitu perlakuan 3 (kacang merah yang ditambah $10 \%$ tepung sagu dan $0,5 \%$ kapur), dan perlakuan 7 (kedelai yang ditambah $10 \%$ tepung sagu dan $0,5 \%$ kapur). Penampilan pertumbuhan miselium pada media biji-bijian disajikan pada Gambar 4. Hasil penelitian ini membuktikan bahwa biji-bijian (kacang hijau, kacang merah, jagung, kedelai, dan sorgum) dapat digunakan sebagai media tumbuh miselium untuk menghasilkan biakan induk jamur sagu. Hasil analisis statistik menunjukkan antara satu perlakuan dengan perlakuan lainnya terdapat perbedaan yang nyata dalam hal kecepatan pertumbuhan miselium, hal itu diduga disebabkan oleh komposisi kandungan nutrisi masing-masing biji-bijian yang digunakan berbeda antara satu dengan lainnya. Hal yang serupa juga dilaporkan oleh Beausejour (1999), yaitu menjumpai perbedaan pertumbuhan miselium pada media biji gandum dan rye. Media biji-bijian yang paling sesuai dan sangat cocok untuk mendukung pertumbuhan dan perkembangan miselium adalah biji sorgum. Hal yang serupa juga diamati oleh Mshandete dan Cuff (2008), pada tiga macam genus jamur edibel. Pada dasarnya untuk tujuan usaha jamur sagu, biji-bijian dari sereal atau legum apa saja yang mudah diperoleh dapat digunakan sebagai media tumbuh untuk menghasilkan biakan induk jamur sagu.

\section{SIMPULAN}

Tetua jamur sagu yang digunakan sebagai sumber eksplan merupakan jamur sagu yang tumbuh secara alami (wild types) di tempat buangan ampas sagu masyarakat. Tetua donor eksplan yang digunakan memiliki ciri morfologi berbeda dengan jamur merang dan jamur edibel lainnya yang telah diidentifikasi. Media yang dapat menginduksi pertumbuhan jaringan stipe dengan baik menjadi hifa adalah media MS dan KN yang diperkaya dengan air kelapa 15\%-30\%. Proliferasi hifa menjadi hifa yang vigour, tumbuh dengan cepat, dan melimpah adalah juga media MS dan KN yang diperkaya dengan air kelapa 15, 3, dan 45\%. Tidak ada perbedaan di antara perlakuan air kelapa yang dicobakan pada proses proliferasi hifa jamur sagu. Pada dasarnya semua formulasi media biji-bijian yang digunakan pada penelitian ini dapat digunakan sebagai media untuk menghasilkan biakan induk (spawn stages) jamur sagu. Formulasi media sorgum (perlakuan 9 dan 10) merupakan media yang terbaik menginduksi pertumbuhan dan perkembangan miselium menjadi biakan induk.

\section{UCAPAN TERIMA KASIH}

Ucapan terima kasih disampaikan pada pengelola proyek Hibah Strategis Nasional dengan kontrak No. 0246.0/ 023-04.2/XXX/2009 yang bersumber dari DIPA Universitas Negeri Papua atas dukungan dana penelitian yang diberikan sehingga penelitian dapat terlaksana sebagaimana mestinya. Ucapan terima kasih juga disampaikan kepada semua pihak yang telibat pada penelitian ini. 


\section{DAFTAR PUSTAKA}

Abbas, B, Listyorini, F.H \& Martanto 2011. Karakteristik jamur sagu (Volvariella sp.) endemik Papua. Jurnal Natur Indonesia 13(2): 168-173.

Atkin, F.C. 1995. Guide to Mushroom Growing. London: Faber and Faber Queen Aqure.

Beausejour, T.M. 1999. Getting started with mushroom cultivation. A MycoWeb Page, Copyright@Michael Wood. http://www.mycoweb.com/article/cultivation. html (5 Juni 2010).

Chang, S.T. 1983. A morfological study of Volvariella volvacea. The Chung Chi Journal 91-103.

Chang, S.T \& Hayer, W.A. 1978. The Biology and Cultivation of Edible Mushroom. New York: Acad Press.

Chang, S.T. 1999. Global impact of edibel and medical mushroom on human welfare in the $21^{\text {st }}$ century. Int $J$ Med Mushroom 1: 1-7.

Cordeiro, M.S., Silva, E.H.S., Miranda, M.S., Biondi, F.C., Santos, S.S.D \& Ohashi, O.M. 2006. The used of coconut water solution (Cocos nucifera) as a holding medium for immature bovin oocytes for in vitro embryo production. Anim Reprod 3(3): 376-379.

Dodds, J.H \& Roberts, L.W. 1986. Experiment in Plant Tissue Culture. $2^{\text {nd }}$ ed. America: Cambridge University Press.

George, O.L \& Sherrington, P.D. 1984. Plant Propagation by Tissue Culture. Hand Book and Directory of Commercial Laboratories. England: Exegetics Ltd.

Istimewa. 2008. Jamur kaya nutrisi dari limbah pertanian. http://www.ilmupedia. com/akademik/ 29/615-jamurkaya-nutrisi-dari-limbah-pertanian.html (22 Juli 2009).

Jordan, M. 1993. Edibel Mushroom and Other Fungi. London: Blanford.

Khayri, J.M.A., Huang, F.H., Morelock, T.E \& Busharat, T.A. 1992. Spinach tissue culture improved with coconut water. Hort Science 27: 357-358.

Kuo, M. 2008. The Genus Volvariella. Retrieved from the mushroom Expert. http://www. mushroomexpert.com/ volvariella.html (17 April 2009).

Li, G.S.F. 1982. Morfology of Volvariella volvacea. Di dalam Shu-ting Chang, T. H. Quimio (eds) Tropical mushrooms: biological nature and cultivation methods. Pp.117-160. Science. books.google.com books?isbn=9622012647 (20 Juli 2009).

Minh, T.V. 2001. Application of tissue culture techniques in woody species conservations, improvement and development in Vietnam: Mangosteen (Garcinia mangostana L.) via embryogenesis culture. Physiol plant 15: 473-479.
Mohi, L. 2007. Jamur multi manfaat dan pasar luas. http://ikm.depperin. go.id/ Publikasi. Promosi/ KumpulanArtikel/tabid/67/articleType/ArticleView/ articleId/25/Jamur-Multi-Manfaat-Pasar-MakinLuas.aspx (10 April 2009).

Moncalvo, J.M., Vilgalys, R., Redhead, A., Johnson, J.M., James, T.Y.,Aime, M.C., Hofstetter, V., Verduin, S.J.W., Larson, E., Baroni, T.J., Thorn, R.G., Jacobsson, S., Clemencon, H \& Miller, O.K. 2002. One hundred and seventeen clades of euagarics. Molecular Phylogenetics and Evolution 23: 357-400.

Mshandete, A.M \& Cuff, J. 2008. Cultivation of three types of indigenous wild edible mushroom: Cprinus cinerius, Pleurotus flabellatus, and Volvariella volvocea on composted sisal decorication residue in Tanzania. Afr J Bioteknol 7(24): 4551-4562.

Mukhtar, R., Khan, M.M., Rafiq, R., Shahid,A \& Khan, F.A. 2005. In vitro regeneration and somatic embryogenesis in Citrus aurantifolia and Citrus sinensis. Int J Agri Biol 7(3): 518-520.

Muhammed, M \& Vladimir, B. 2007. Method of preparation and use of coconut water in mamalian tissue nourishment growth and healthy maintenance. http://www.freepatentsonline.com/7300682.html (16 September 2009).

Osemwegie, O.O., Eriyamremu, G.E \& Abdulmalik, J. 2006. A survey of macrofungi in Edo/Deltaregion of Nigeria, their morfology and uses. GJPAS 12(2): 149-157.

Pierik, R.L.M. 1987. In Vitro Culture of Higher Plants Martinus. Netherlands: Higoff Publ.

Piexe, P., Raposo, A., Lourenco, R., Cardoso, H \& Macedo, E. 2007. Coconut water and BAP successfully replaced zeatin in olive (Olea europaea L.) micropropagation. Scientia Horticulturae 113: 1-7.

Roy, B \& Mandal, A.B. 2005. Anther culture response in Indica rice and variations in major agronomic characters among the androclones of a scented cultivar, Karnal local. Afr J Biotechnol 4(3): 235-240.

Santoso, H.B. 2003. Air Kelapa, Limbah Penuh Khasiat. h t t p : / / w w w.gizi .net/cgi - bin/berit a fullnews.cgi?newsid1068615913,84324, (3 September 2009).

Syafii, W,. Bey, Y \& Gusmarini. 2000. Pengaruh air kelapa terhadap pertumbuhan tunas melon (Cucumis melo var. Honey dew) pada kultur jaringan. Jurnal Natur Indonesia 2(2): 132-137.

Widiyastuti, B. 2005. Budidaya Jamur Kompos. Jamur merang dan Jamur Kancing. Jakarta: Penebar Swadaya. 